\title{
David Malcolm Raup (1933-2015) at the starting point of a new paradigm for Palaeontology
}

\author{
Miquel DE RENZI
}

Cavanilles Institut, Universitat de València, c/ Catedrático José Beltrán Martínez 2. 46980 Paterna-Valencia, Spain; miquel.de.renzi@uv.es

De Renzi, M. 2017. David Malcolm Raup (1933-2015) at the starting point of a new paradigm for Palaeontology. [David Malcolm Raup (1933-2015) en el comienzo de un nuevo paradigma en Paleontología]. Spanish Journal of Palaeontology, 32 (1), 129-146.

Manuscript received 1 December 2016

Manuscript accepted 12 April 2017

(C) Sociedad Española de Paleontología ISSN 2255-0550

\begin{abstract}
This is a tribute to the late David Malcolm Raup, one of the major palaeontologists of the second half of the $20^{\text {th }}$ century. In addition, it is a critical review of his outstanding contributions, mainly in the field of theoretical palaeontology: quantitative modelling, the introduction of probabilistic methods in palaeontology, as well as his great imagination to use techniques from other fields, such as insurance actuary. After a general outline of his youth, I present a general depiction of the main topics of his research as a palaeobiologist: morphology, the structure of the fossil record, evolution, and extinction. He covered areas ranging from the theoretical morphology of coiled shells to the use of Montecarlo methods in evolution and extinction, or the periodicity of mass extinctions and its causes, as well as the episodic nature of background extinctions, which were some of his preferred subjects. With his textbook, coauthored by Steven Stanley, he introduced a new paradigm for palaeontology.
\end{abstract}

Keywords: Fossil record, evolution, extinction, time series, simulation.

\section{RESUMEN}

Este es un homenaje al difunto David Malcolm Raup, uno de los mayores paleontólogos de la segunda mitad del siglo XX. Es, además, una revisión crítica de sus aportaciones más destacadas, principalmente en el campo de la paleontología teórica. Éstas fueron la modelización cuantitativa, la introducción de métodos probabilísticos, así como su gran imaginación en el uso de técnicas procedentes de otros campos, como las matemáticas de los seguros. Tras un breve perfil de su juventud, se presentan los principales temas de su investigación paleobiológica: morfología, estructura del registro fósil, evolución y extinción. Cubrió áreas que van desde la morfología teórica a los métodos de Montecarlo en evolución y extinción, o la periodicidad de las extinciones en masa y sus causas, así como la naturaleza episódica de la extinción de fondo, que fueron algunos de sus temas preferidos. Con su libro de texto, escrito junto a Steven Stanley, introdujo un nuevo paradigma para la paleontología.

Palabras clave: Registro fósil, evolución, extinción, series temporales, simulación.

Para Pascual Rivas, en recuerdo de nuestras discusiones sobre la morfología teórica de Iberus, en aquel ya lejano 1981. 


\section{INTRODUCTION}

David Malcolm Raup, one of the most outstanding figures of the new ways opened for palaeontology since the forties of the $20^{\text {th }}$ century, died on 9 July 2015 in Sturgeon Bay (Wisconsin), after a very productive and innovative scientific life. He was born on 24 April 1933 in Cambridge (Massachusetts), and he was 82 years old at his death. He was invited as a lecturer at two international and important meetings held in Spain: Concept and Method in Paleontology (Barcelona, 1981), organized by Jordi Martinell (Fig. 1), and Palaeontology and Evolution: Extinction Events (Bilbao, 1988), organized by Marcos A. Lamolda.

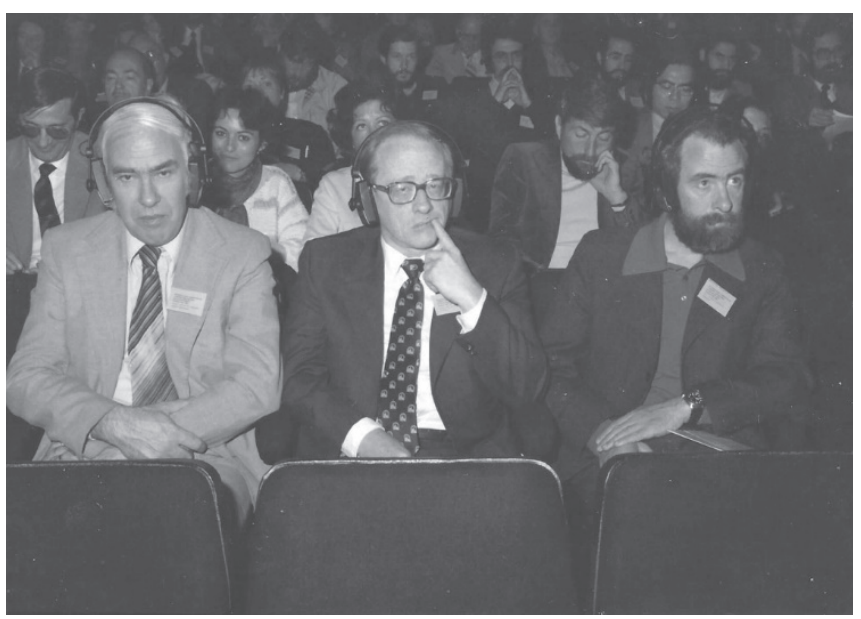

Figure 1. David M. Raup, between Anthony Hallam (left) and Richard Bromley (right), attending at the International Symposium Concept and Method in Paleontology in Barcelona (1981). By courtesy of Jordi Martinell.

In order to understand the role of David M. Raup in the development of modern palaeontology since the sixties, we need to know the state of the art since the last quarter of the $19^{\text {th }}$ century until 1944 , which was a turning point in the history of palaeontology. During this interval, palaeontology remained as a descriptive discipline linked to their purely unimaginative applications to geology, especially biostratigraphy. This ancillary position, without own objectives, was a consequence of its use in oil prospection since the last quarter of the $19^{\text {th }}$ century (Rudwick, 1972; Lipps, 1981; De Renzi, 2005). In 1944, a landmark date for our discipline, Simpson published his seminal book Tempo and Mode in Evolution (Simpson, 1944), which triggered a change of focus in topics for palaeontology by showing the fossil record as an essential tool in the study of organic evolution.

Palaeontology had been a promising field of knowledge at its early beginnings, in the first decades of the $19^{\text {th }}$ century. Names such as Cuvier, Brongniart, Lyell, or D'Orbigny centred their research on the biological problems raised by fossils; i.e., they worked as genuine palaeobiologists. They focus on many issues, such as, relationships between form and function (Cuvier); traits of the old environments; e.g., climate, as reflected by fossils (Brongniart); positioning about the problem of how species arise, as Lyell (1832) reviewed (see Rudwick, 1972), or even the first attempts to quantify diversity throughout geologic time by D'Orbigny (Manceñido \& Damborenea, 2003). The new way opened in 1944 for palaeontology consisted of the recovery of this initial attitude as a paradigm for our science, and David M. Raup was an active part in its establishment.

Raup's contributions to modern palaeobiology came from the use of quantitative modelling in fields as different as morphology or clade simulations, the study of the fossil record based on the analysis of temporal series, or the relevance of chance in our understanding of the evolutionary or extinction processes. The way in which he arrived to these achievements, however, didn't follow a straightforward path, and we need some information about his origins before exposing the several aspects of his scientific work. My purpose is not only to pay a tribute to David M. Raup but also to carry out a critical review of his main contributions and ideas, as well as to explore some details about their genesis.

\section{RAUP'S BEGINNINGS}

"I feel in a somewhat strange position today as the first president of The [Paleontological] Society who has never described a species.

Description provides the basic observations that must be the test of any theory and theoretical work brings up new things to look for a new question to ask".

Raup (1978a; presidential address to The Paleontological Society)

David was the son of Hugh and Lucy Raup. Hugh, his father, was professor of botany at the University of Harvard and head of ecological research at the Harvard Forest. Lucy, his mother, was a teacher who studied lichens (Erwin, 2015). From his own account (my main source of information for this paper is an interview with David M. Raup carried out by David Sepkoski; Sepkoski \& Raup, 2009), the first steps of his education in geology were at Colby College (Maine), and later he moved to Chicago as an undergraduate transfer, where he completed the geology undergraduate. Another source tells us that he studied also mathematics and accounting at Colby College (Rafferty, 2015). 
When he finished his undergraduate studies, he could find in Chicago an excellent adviser in the key figure of Everett C. Olson (1910-1993). Olson is considered as one of the greatest American vertebrate palaeontologists (Bell, 1998), with an important training on both, geology and biology. Olson also introduced taphonomy after a travel to the old USSR in the middle of the Cold War, and he is known by a seminal book for understanding morphological complexity (Olson \& Miller, 1958). However, a disagreement arose astonishingly between the young David and the advanced mathematical applications to palaeontology of Olson! In short, in this time, Raup wanted a more traditional approach to palaeontological research. In other words, a practice focused on collecting, describing and classifying fossils, with application to biostratigraphy. The interest of Olson in numbers or models was not his interest ('too theoretical for use' according to Raup's own words). He also criticised the looseness of the programme. He looked for a university fulfilling his desiderata, and after several attempts, he returned to Harvard, where his father Hugh had met a palaeontologist of German origin and very traditional training, Bernhard Kummel (Newell, 1981). David introduced himself to Kummel and found at last the mentor that he looked for. Although traditionally minded, Kummel animated his students to develop their own scientific personality, as well as to publish their ideas if possible.

This raises a question: how did Raup become one of the major innovators of $20^{\text {th }}$ century palaeontology with such approaches? Perhaps, the answer was not only the liberality of his new mentor but the splendid scientific environment at Harvard too. I remark the influence exerted on the young David M. Raup by Norman D. Newell and John Imbrie, but above all Ernst Mayr, one of the founders of the modern synthesis of evolution. Newell alternated his research on Texas Permian reefs with the study on their recent counterparts in the Bahamas with many students, and John Imbrie was among them. Thus, they carried out a neontologic approach for a palaeobiological research. In addition, Newell and Mayr interacted at that time in the American Museum, and David acquired his initial knowledge in statistics in a course on population genetics at Harvard; he ignored statistics until that moment. Raup visited also John Imbrie in New York, who was his real teacher on biometrics and applied statistics.

The role of Ernst Mayr deserves a more precise comment. Mayr indirectly suggested his dissertation topic, because David had interest in fossil echinoderms since the Chicago times. Mayr had just finished a paper on living sea urchins around the world, dealing with topics of biogeography and speciation, and was interested in somebody working on similar subjects in the fossil record. David could study large collections looking for phyletic change and geographic speciation in sequences of fossil echinoids, with application of the biometric techniques and applied statistics learnt from Imbrie.

Raup seems to have made contact with computers in an almost accidental way, because when he was finishing his PhD work he had an appointment at Johns Hopkins to study sand fleas (small intertidal arthropods) on the sand beaches of the south-eastern United States. These animals were living within radioactive black sands, and there was interest on the possibility of mutagenic action of radiation on them. He carried out a lot of biometric studies, but he didn't find any of the expected results related to radioactivity. His biometric studies led him to plot data and generated many graphics in a manual way, so he decided to learn computer plotting with FORTRAN language at Johns Hopkins in a time, the sixties, in which computers were anathematised by palaeontologists.

As a result, David M. Raup went from a traditionalminded viewpoint in palaeontology to a progressively broadened perspective that included those despised numbers and models ('too theoretical for use'), as well as a palaeobiological perspective. As mentioned above, Raup never described a species, as said by himself when he was elected president of The Paleontological Society (Raup, 1978a), but he recognised the importance of the welldone systematic and descriptive activity for stimulating or testing new theoretical issues. At the same time, theoretical issues encourage to look for new observations and new problems. For Raup, the excellence was reached by palaeontologists of great level in both descriptive and theoretical fields, such as Osborn or Schindewolf.

From this point onwards, I am going to draw a portrait of Raup as a palaeobiologist and take into account his position as one of the founders of the new paradigm of palaeontology. He worked on morphology, and dealt with the difficulties and conflicts involved in a direct reading of the fossil record. He also worked on evolution and extinction with a non-deterministic, stochastic approach. He dealt with all these subjects using modelling and quantification.

\section{ON MORPHOLOGY}

The first field on which Raup worked from a palaeobiologic viewpoint was morphology. He conceived morphology from an evolutionary approach, but he advanced in this field from the simple to the complex. His first papers dealt with the very specific features of the echinoid plates, as their optical properties, but he was simultaneously immersed in a revolutionary approach, as it is theoretical morphology. Finally, he was the introducer, in English language, of a new way to study the organic form: the Seilacher's Konstruktions-Morphologie, and its 
consequences on the evolutionary biology of development (evo-devo), an emergent discipline, especially referred to the role of developmental constraints in evolution.

\subsection{The echinoid plates}

His approach addressed the mineral character of the skeletal plates in a large sample of regular echinoids (mainly living forms, but also including fossils). Echinoderm plates consist of single calcite crystals with characteristic optical properties. These plates are porous, and their pores contain living tissue while the animal is alive. When the animal dies, tissues decay quickly and plates become empty. During the fossilization processes, the pores are filled by new calcite (permineralization) in crystallographic continuity with the original mineral, so the optical properties of plates remain unchanged. Thus, concluded Raup, palaeobiological studies could be carried out with confidence.

He studied the orientations of the $c$-axis in both coronal plates (Raup, 1959) and those of the apical system (Raup, 1965). I cite two papers among a total of seven. Older studies of crystal orientation (since 1887) were subjected to large errors ( $\sim 25^{\circ}$ oscillation). Raup used the four-axis universal stage coupled to a petrographic microscope increasing accuracy (only $1^{\circ}$ oscillation). Coronal plates (Raup, 1959) showed two kinds of orientations, with small variation within a species, and were nearly homogeneous for genera and families, in a strict control regardless of ontogeny. In addition, these two orientations arose several times in the history of echinoids in an independent way. This had to do with natural selection for mechanic (cleavage) or optical (sensitivity to light) characteristics. However, orientations of the plates in the apical system were not referred to the adult, as in coronal plates, but were established before the metamorphosis, and reflected the larval bilateral symmetry. Therefore, according to Raup, this trait could be used as a taxonomic character.

Adaptive interpretations were in connection with his time, above all because he could have been strongly influenced by Ernst Mayr. It has to be into consideration that Mayr was one of the founders of the modern synthesis, and therefore, he was an advocate of adaptation promoted by natural selection. However, Raup was going to change his point of view in a few years.

\subsection{Theoretical morphology}

Although theoretical morphology was not a new subject, Raup contributed to its revival throughout the sixties with new approaches. This revival is considered one of Raup's main contributions not only to palaeontology but also to biology. In the $19^{\text {th }}$ century, the German Naturphilosophie suggested that the modifications of a single structural plan were the source of the possible existent morphologies of a group. This was probably Raup's theoretical and philosophical support, from Emmanuel Kant to Étienne Geoffroy Saint-Hilaire and Johan Wolfgang Goethe (see Richards, 1992). More specific contributions (logarithmic -equiangular- spiral in shells) came from Réaumur, Mosley, and above all D'Arcy W. Thompson (Raup, 1961). Thompson (1942) could not explore the consequences of this model since it required computer simulations, which were not available in his time.

Raup addressed a very specific problem: the geometry of isometric coiled shells, which embraces so different animals as molluscs (gastropods, cephalopods and bivalves), brachiopods, or even forams (although he did not work with this latter group). The basic idea was that the logarithmic spiral is common to all these kinds of shells, and partly associated to isometry. This spiral is expressed by a vector whose magnitude grows exponentially with the turning angle around the coiling axis. This is a geometric element of shells, which may be inferred and traced. Why isometry? In gastropod shells, Raup (1961) provided several evidences for this assumption: in a single shell, the shape and the rate of expansion of the generating curve, the relative amount of overlap of one whorl on the precedent one, as well as the ratio relating the size of the generating curve to the distance between the axis coiling and a given point on the generating curve, remain constant. This constant shape of gastropod shells allows describing them quantitatively instead of using traditional qualitative descriptions, e.g. the series turriculate to obconical (a function of changing in the amount of whorl overlap) or the series naticiform to turriculate (a function of changing whorl expansion rate). This finding proved to be useful in many kinds of studies, from ontogeny to ecology.

Raup was going to use computers in order to display all the consequences contained in the hypotheses of Thompson (1942), as well as his own conjectures. He mentioned (Sepkoski \& Raup, 2009) that during the sixties 'computers were anathemas to most palaeontologists'. Thus, he was going to challenge his own scientific community. Raup (1962), in his paper about gastropod shells, claimed explicitly to reproduce with a digital computer equipped with an automatic plotting device the basic forms of many gastropod shells under the assumption of four constant basic parameters. They referred to the shape of the generating curve, its position relative to the coiling axis, the rate of increase of this curve in size, and the curve's rate of translation along the coiling axis, which Raup \& Michelson (1965) named as $S, D, W$ and $T$, respectively. Some specific values of the parameters $D$ and $T$ deserve some comments: thus, $D \neq 0$ describes umbilicate shells, and $T=0$, planispiral shells. In addition, Raup (1962) was aware that the condition by which the four parameters remain constant is not always accomplished, i.e. allometry. Therefore, in those cases in which it might be necessary, the rate of expansion of the generating curve 
would decrease regularly with each revolution around the axis. Nowadays, the answer of one of the referees of this submitted manuscript might seem bizarre to many of us: one of the reviewers said explicitly that its content 'was not science'! (Sepkoski \& Raup, 2009; p. 463).

These were part of the adventures and misadventures in the first steps of modern theoretical morphology by the hand of David M. Raup. In the following years, he published four new papers (Raup, 1966, 1967; Raup \& Michelson, 1965; Raup \& Graus, 1972), in which he developed progressively his ideas in this field. He coined the term 'theoretical morphology' as applied to its current use (Raup \& Michelson, 1965). He also proposed a 'fourdimensional' space or 'morphospace' whose axes were defined by the four parameters. The morphospace contains all the possible morphologies of isometric-coiled shells and an explicit mathematical model in cylindrical coordinates simulated them. Simulation was carried out with an analog computer and oscilloscope, which provided perspective views of the coiled surfaces; this was the contribution of the engineer Arnold Michelson. The novelty consisted on the representation not only of actual types but also of those not found in nature. Thus, he set out to explore the causes by which these non-evolved shapes had not come into existence (Raup \& Michelson, 1965; Raup, 1966). Explanations were basically functional-adaptive, so, he put emphasis on functional factors depending on shell geometry in ammonoids: orientation or stability for swimming in the life position, or carbonate efficiency in building the coiled shell (Raup, 1967). This last kind of condition required general equations of volume and surface of a coiled shell obeying to the logarithmic spiral model (Raup \& Graus, 1972).

Some regions of this morphospace represent analogues of real forms of gastropods and bivalves (trochospiral), as well as ammonoids and brachiopods (planispiral). A large part of this morphospace, however, is empty; that is, regions of geometrically possible combinations of $W, D$ and $T$ that have no correlate in nature (the fourth dimension, $S$, is obviated since the shape of the generating curve is reduced to a circumference). Why has evolution favoured some regions but no others? This fact required explanation and Raup pointed out some hypotheses but in a general way. In the case of bivalved shells, the possible interpretations stated that efficient bivalve hinge requires that whorls don't overlap or that regions non-occupied by bivalved shells represent coiled surfaces with overlapping whorls.

Raup asked if the parameters $W, S, D$ and $T$ would have a genetic basis (Raup 1961). I think again that this was due to the very influential presence of Ernst Mayr and his high position within the modern synthesis. The same can be said of, at the end of his 1966 paper, when he raised the question of why no bivalve develops planispiral shells as brachiopods do, and concluded that it was a poor answer to say that this was due to chance because to do so "is to discard the question and thereby to ignore a rigorous functional explanation' (my italics). He was going to adopt later a more critical attitude towards functionalism at the same time that, for him, chance (i.e. contingency in history) was going to acquire relevance as a factor in macroevolution.

Raup still developed morpho-theoretical work about helical bryozoans such as the extinct Archimedes or the extant Bugula, which simultaneously show a branched pattern. He devoted two papers to these topics (McKinney \& Raup, 1982; Raup et al., 2006). In order to finish this section on theoretical morphology, I shall speak about the theoretical morphology of behaviour after Raup. Traces of benthic motile invertebrates looking for particulate food on the sediments of the sea bottom show complex morphologies reflecting complex behaviours, above all in deep deposits (turbidites), where food is evenly distributed on the sediment surface. Raup collaborated with Adolf Seilacher, the outstanding figure of ichnology since the end of the sixties, who knew all the previous work on traces of living organisms. It was clear for Seilacher that these complex geometries are not due to chance but obey a short number of simple rules for optimizing search for food on sediment surfaces, as concluded in previous studies. Raup understood that these rules could be translated to computer instructions and both Seilacher and Raup joined their efforts and produced a short but very important paper (Raup \& Seilacher, 1969). They started from those precedent studies and managed to simulate, by means of a digital computer with $\mathrm{x}-\mathrm{y}$ plotter output, many natural patterns obeying a small number of well-specified rules (Fig. 2).

A last remark about the concept of morphospace: a decade before Raup coined this term, Miquel Crusafont and Jaume Truyols, two Spanish palaeontologists, published three seminal biometrical studies (Crusafont \& Truyols, $1956,1957,1958)$. They elaborated a scheme that might be interpreted, with our current perspective, as a true empirical morphospace characterising biometrically the different families of fissiped carnivores. Such approach was an advanced precedent of Raup's idea (see Palmqvist, 2016).

\subsection{From Konstruktions-Morphologie to evo-devo}

In 1970, Adolph Seilacher published a very short paper in which he interpreted the organic form in a very original way (Seilacher, 1970). Organic form was explained by the modern synthesis in terms of optimal functionality, or compromises when several functions are in conflict. Seilacher took into account, however, the phylogenetic legacy, which constrains adaptive solutions, as well as morphogenetic programmes whose changes are not connected with adaptation and function. In this conceptual framework, which Seilacher called Konstruktions- 

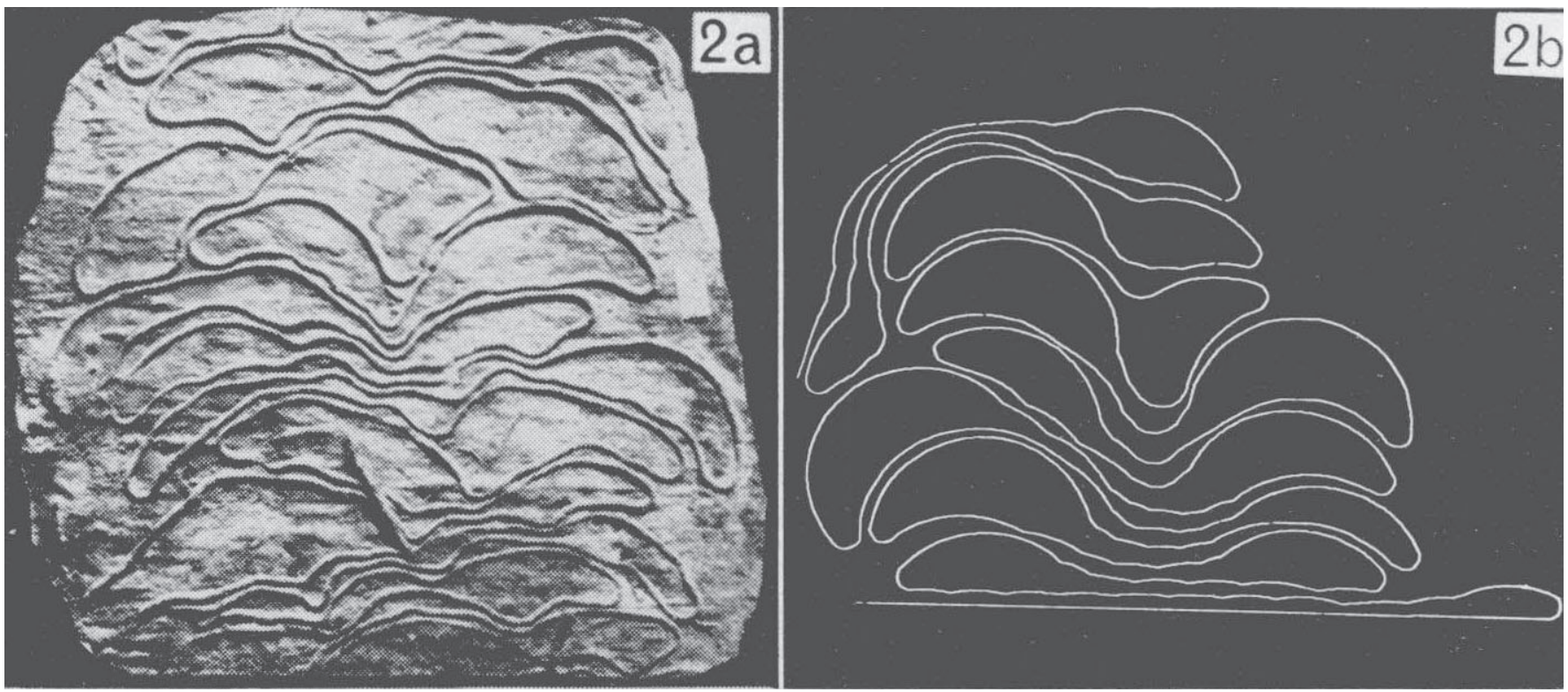

Figure 2. Theoretical morphology of behaviour as reflected by fossil traces. Rules of animal movement are very simple and easy to implement as instructions of a digital computer programme (see text). On the left (2a), a real complex meander from the Italian Cretaceous flysch; on the right (2b), the similar computer output. From Raup \& Seilacher (1969), with permission of Science.

Morphologie, function and adaptation (Ökologischadaptiver Aspekt) are strongly constrained by the phylogenetic legacy (Historisch-phylogenetischer Aspekt), and the technical features related to the morphogenetic programmes from which the different organic structures develop (Bautechnischer Aspekt). This meant a 'German' revolution in the understanding of morphological evolution.

One year later, Seilacher held a workshop at the University of Tübingen, with the purpose that many researchers from Germany, working on morphological topics, exposed their results under the premises of the Konstruktions-Morphologie. A few special foreign guests attended the workshop. From the United States came David M. Raup, Stephen Jay Gould and Richard Jefferies. Gould (1971) wrote the account of this meeting in a short note. However, Raup wrote an extended paper (Raup, 1972a) in a book that claimed to be an innovative scenario for palaeontology, and addressed to the palaeontological community: Models in Paleobiology.

Raup's role in this paper was to introduce Seilacher's approach to the non-German speaking palaeontologists. In addition, he gave a number of very illustrative examples, and made a methodological proposal for research in the new framework. A first step was the translation of the new terminology from German to English language. He didn't translate the German name as Constructional Morphology, as Seilacher (1970) did in the abstract of his paper; instead, Raup didn't propose any name for this framework. He, however, proposed the terms historicalphylogenetic factor (Historisch-phylogenetischer Aspekt), structural factor (Bautechnischer Aspekt), and functional factor (Ökologisch-adaptiver Aspekt).

In this paper, Raup evidenced the antithetic positions of Schindewolf's "typostrophism" (non-adaptive or inadaptive characters in the early stages of the expansion of a clade) and Simpson's synthetic theory of evolution ("all morphology is adaptive"); both points of view are 'allexplanatory' systems (Grene, 1958a, 1985b). Therefore, these systems are closed in themselves when explaining morphology (see also Rudwick, 1964). According to Raup, Seilacher clarifies the situation since he doesn't adhere to any of these two positions but recognizes both adaptive and non-adaptive traits arising throughout evolutionary processes. This could mean a change in Raup's perspective.

Raup seemed very enthusiastic with the original point of view of Seilacher in writing this paper. Moreover, he wanted to add two new factors: ecophenotypic effects and chance. The discussion of the validity or non-validity of these new factors proposed by Raup is beyond of the scope of this paper, but I only describe them. The first is referred to the norm of reaction to the environment; that is, phenotypic plasticity of each individual organism during its life cycle, which in general can produce individual adjustment to some specific features of the environment, or it can be only a simple answer to them. The other factor he added to the Seilacher's scheme was chance. Raup dealt with chance in adaptation in discussing the possible paths of phylogeny climbing from the less to the more adaptive situations in a Sewall Wright's adaptive landscape. Adaptive optimum corresponds to the highest peak. 
However, given the chance involved in the evolutionary process, a lineage always ascending in adaptive level doesn't necessarily reach the highest peak but an adjacent lower peak. It is important to say that Raup, with these last remarks, began to abandon his early position in favour to adaptation as the main factor of evolution. In addition, one of the leitmotivs in his subsequent career appears here: the stochastic features of evolution, which I shall deal with below.

A very interesting contribution in Raup (1972a) was the proposal for a research methodology in KonstruktionsMorphologie. This proposal was the use of simulation models as aids to morphological analysis based in contemporary issues applied to geology. He gave a main classification of simulation models in three dichotomous pairs: physical (with material analogues) or symbolic (in terms of computer instructions); dynamic or static (with or without feedback at each step of simulation), and probabilistic or deterministic (involving or not stochastic features at each step). Each term of each pair can be combined with terms of the other two pairs so that eight possible groupings appear: physical-dynamic-deterministic models, physical-static-deterministic models, and so on. I shall give some examples. A physical-static-deterministic model would be that of Rudwick (1961) for the feeding mechanism of the brachiopod Prorichthofenia, simulated by a physical model with flapping mobile structures simulating valves (functional factor). As a symbolic-static-deterministic model, he proposed his own model for describing the isometric coiling (Raup \& Michelson, 1965), which could be used in the research of phylogenetic constraints.

Between the end of the sixties and the early eighties an important aspect for understanding evolution was reinstated: embryonic development. This was the consequence of the publication of a seminal book, Ontogeny and Phylogeny (Gould, 1977), followed by another seminal paper by Alberch et al. (1979). Immediately, Alberch (1980, 1982) laid the foundations for understanding the regulative and constraining role of development in evolution. These studies contributed to the arising of a new branch of evolutionary biology: the evolutionary biology of development or, shortly, evo-devo (see a review and analysis of the early work of Pere Alberch, which connects his ideas with Seilacher' scheme, in De Renzi, 2009).

The notion of developmental constraint generated a discussion reflected in an important paper in which Raup participated (Maynard-Smith et al., 1985). His contribution to the discussion was an extended example based on shell coiling. It is a reflection about the selective or developmental constraints operating on 'open' coiled shells (their successive whorls don't overlap) versus those shells whose successive whorls are in contact (they do overlap). A great majority of molluscan shells have whorls in contact. Raup thought that this was mainly due to biomechanical reasons; shells are more resistant, and therefore protective for the animal, if their whorls are in contact. In addition, this condition requires lower amounts of calcified material. Since there are exceptions, he found reasons for them, as in the case of the cephalopod Spirula, in which the shell is 'open'; this is an internal shell without protective character for the animal. It is the body of the animal that protects such a fragile structure, and its only function is for buoyancy. However, for Raup there was a case, unrelated to those previous ones, and due to a developmental constraint. Pholads are bivalves that maintain the logarithmic spiral. They are rock or wood borers, and produce a rotary motion of their body that should result in perfect cylindrical holes, but such behaviour is not associated to the bivalve shell. Selection has strongly worked as constrained by the growing logarithmic spiral of the shell, and if no optimal, the product is a hole section more or less circular. Therefore, Raup concluded that there would be a developmental constraint leading to a logarithmic spiral.

\section{THE INTRODUCTION OF A NEW PARADIGM FOR PALAEONTOLOGY}

The sixties and the earlier seventies of the $20^{\text {th }}$ century were a time with exciting approaches for a renewal of palaeontology from its decadent situation (see Introduction). Journals of large diffusion began to publish not only the traditionally-oriented papers on systematic palaeontology or biostratigraphy but also others with a marked palaeobiological orientation. I cited above Rudwick (1964), for the feeding mechanism of a Permian brachiopod. It was a paper exposing the foundations of the research in functional morphology applied to fossils. Another case is that of Beerbower \& Jordan (1969), with the first attempt to apply to palaeoecology Margalef's diversity index based on information theory. They are only two examples coming from a large amount of such kind of papers in mainstream journals. Near the end of the sixties (1968) a new journal, more prone to palaeobiological topics as was Lethaia, appeared. In addition, several books were published on the subject of the relationships among extinct animals and plants, or their relationships with their environment; that is, their ecology, or more properly, palaeoecology (e.g. Ager, 1963; Imbrie \& Newell, 1964). However, as I said in the Introduction, the initial revival of the palaeobiological approach began in the forties when fossils were used again to explain evolution (Simpson, 1944, 1949). Lastly, I must cite the growing interest on the processes leading to the formation of fossils from the biosphere in a new approach called taphonomy by Efremov $(1940,1950)$. These processes cannot be defined neither as typically geological nor biological. 
However, the bifurcation point was the publication of the book edited by Schopf Models in Paleobiology (Schopf, 1972). It had its origin when Thomas Schopf realized that many palaeontologists were unaware of research strategies different from simple description of fossils coming from single or different related formations. Therefore, he conceived the need of showing, to the palaeontological community, different modelling strategies, using mainly organisms from which fossils were originated (palaeobiological research). Raup contributed to this book a paper on an alternative way to see morphology and its evolution (see section 3.3 above). The next step was the need of a specialized journal on palaeobiological topics. This happened in 1975, with the appearance of the first issue of Paleobiology. Thus, it seems that a new paradigm for palaeontology laid its foundations at that time.

In this context, I would like to remember an important event of renovation in Spain that started at the University of Barcelona, driven by Jordi Martinell, currently professor of palaeontology at that university: The International Symposium Concept and Method in Paleontology. This event took place more than three decades ago, in 1981 in Barcelona, and there were eleven invited lecturers on topics ranging from theoretical and methodological questions to how to teach or publish in palaeontology. David Malcolm Raup was one of the invited lecturers; he exposed his seminal paper on Galtonian extinction, which I shall comment on.

\subsection{Textbooks as vectors of paradigms}

A paradigm is, according to Kuhn (1971), a theory, or an embryo of a theory, emerging in a specific moment, which gives sufficient explanations for a set of phenomena in a study area, and which influences positively the scientific community to orientate research in the ways of its main theoretical assumptions. I wrote (De Renzi, 1981) that palaeontology, as well as neontology, has a paradigm based on the integration of evolutionary and ecological theories. This is a necessary integration in order to give a theoretical foundation to the disparate fields of knowledge of extant organisms, such as molecular bases, genetics, morphology and physiology, evolution, ecology and biogeography, and so on, which would be translated into a scheme that would relate palaeogeography, palaeoecology and evolutionary palaeontology at each moment in time. This idea came originally from Margalef and was cited by Lawrence (1971).

Since paradigms, following Kuhn, have textbooks as vectors, I also said that textbooks of palaeontology, based on this paradigm, already existed. A first palaeobiologicallyoriented textbook was that of Beerbower (1960). About this book, a reviewer (Collinson, 1960) commented very positively that it was not a traditional textbook of palaeontology but it dealt with updated 'basic zoological and palaeontological principles'; i.e., understanding organic form, population biology, and so on. However, this book had not the expected success. Few people were prepared for such a viewpoint (remember the opinion of the young Raup about the programme of Everett Olson), but it is certainly fair that I cite this book here.

Several years later, a new book, entitled Principles of Paleontology (Raup \& Stanley, 1971), had a great impact comparatively to that of Beerbower (1960), because it included a large amount of palaeobiological papers and ongoing research. It is in this sense that David M. Raup, jointly with Steven Stanley, appears as one of the introducers, in the scientific community, of the new paradigm for palaeontology. It is worth noting the main topics dealt with in its index: preservation and the fossil record, describing a single specimen, ontogenetic variation, the population as a unit, the species as a unit, grouping species into higher categories, and identification of fossils. All these topics were about description and classification of fossils. A second group of topics was the use of palaeontological data, including adaptation and functional morphology, palaeoecology, evolution and the fossil record, biostratigraphy and uses of palaeontological data in geophysics and geochemistry. Unlike the Beerbower textbook, the new book lacked a systematic part.

The book introduces strong palaeobiological foundations: ontogeny, population genetics, Mayr's species concept, numerical taxonomy, and many examples of functional morphology in both invertebrates and vertebrates, with an introduction to theoretical morphology. Palaeoecology is centred basically in marine communities, although something is said about Cenozoic mammal communities. On evolutionary palaeontology, the book follows the main tenets of the modern synthesis, and biogeographical arguments are given for species and speciation. This book had a second edition seven years later (Raup \& Stanley, 1978). Although both authors had worked on new lines (Konstruktions-Morphologie, macroevolution and species selection), the book kept a conservative character, but they provided many new examples. They added, in addition, an extensive chapter on biogeography.

\section{PROBABILISTIC APPROACHES TO PALAEONTOLOGY}

The other great contribution of Raup to palaeontology was, perhaps, the introduction of probabilistic concepts and the analysis of time series. The fossil record consists of a sample of the history of life on Earth, a sample with many biases. The rise and fall of species have the character of a succession of events largely loaded with 
indeterminacy; thus, the most suitable treatment of such sequences of events is a probabilistic one. The structure of the fossil record, as well as the sequences of origination and/or extinction events, require methods based on sampling theory and Markov chains, and other statistical techniques, as I shall review below. Raup was not explicitly an evolutionary palaeobiologist as Stephen Jay Gould was, but he had his own thoughts about evolution as I shall show at once.

\subsection{Interlude: Raup on evolution}

David M. Raup adopted an initial position in agreement with the main paradigms of his time, the evolutionary theory and the ecological theory. I insist that this early point of view could be due to the influence of Mayr thinking on the young David. These theories were characterized as adherent to uniformitarian conceptions coming from Lyell and Darwin, which can be summarized in terms of gradual processes leading progressively towards equilibrium; i.e., evolutionary equilibrium of the biota (originations equating extinctions) and ecological equilibrium (climax attained at the end of the ecological succession). In this ideal situation, extinction was doomed to play a negligible role. Darwin objected the existence of mass extinctions, and thought that they were artefacts due to the imperfect nature of the fossil record, as Lyell did, albeit single extinctions would take place for both authors because of competition between species, with natural selection removing the unfit. Darwin recognized the connection between extinction of older forms and the raising of newer ones, and thus, the function of extinction in the renewal of the biosphere (Darwin, 1859). The modern synthesis, however, neglected the role of extinction.

Raup started with equilibrium models and stochastic modelling of evolution (see Raup et al., 1973). However, Raup's first declaration of principles opposed to those of the accepted paradigms was held probably in 1980, at the $3^{\text {rd }}$ Field Museum Spring Systematic Symposium about crises in ecological and evolutionary time, in which he introduced his idea of crisis and what it meant for biotic systems at all levels (Raup, 1981a). As noticed by Foote \& Miller (2016), Raup was aware that life and the Earth were placed in a "cosmic environment". This was due to the seminal paper of Alvarez et al. (1980) about the evidences of the impact of a large meteoritic body at the end of the Cretaceous period, and the possible attribution to it as the cause triggering the $\mathrm{K} / \mathrm{Pg}$ mass extinction event. Interest on cosmic influences as causes of mass extinction was present in the work of Schindewolf in the fifties, as Hatfield \& Camp (1970) noted. These last authors paid attention to "possible cosmological control of the amount of radiation incident upon the Earth surface" because of the "apparent correlation between periodic galactic events and mass extinctions". In Spain, the book La Evolución (Crusafont et al., 1966) remarked the cosmological frame of life evolution.

Raup (1981a) adopted an alternative position to the current uniformitarianism; namely, that of a world in which crises would play an essential role and catastrophism was reinstated from that moment. He adhered to the conception by which the full understanding of how a biotic system works can only be achieved by observing its behaviour after a sudden disturbance; e.g., fire in a forest. In addition to this, he took into account the conclusions of Eldredge \& Gould (1972) about evolution as a process in which species remain stable until their equilibria become suddenly interrupted by speciation events (punctuated equilibria), another attack against the current uniformitarian gradualism.

A crisis, for Raup, was characterized by its short duration and rarity, its unpredictability within the systems that it will affect, from ecosystems to the global biota, and lastly, its capability to alter, temporarily or permanently, the order of those systems. Raup classified crises into two categories: threshold crises and point crises. The former are those in which an external parameter (e.g. temperature, hydrospheric oxygen concentration), reaches a threshold value. This event cannot be predicted within the system, although the process leading to this threshold is a deterministic one. Point crises are unpredictable, and Raup (1981a) proposed meteorite impacts as a typical case. At that time, the systematic study of extinction phenomena (mass extinctions) began. Raup changed his viewpoint about its unpredictability in the next years, with his analysis of the possible periodicity of extinction events (e.g., Raup \& Sepkoski, 1984). At the same time, he inferred that the background extinction could not be a continuous process but an episodic one. Some years later, Raup (1986a) insisted in the constructive role of extinction in evolution and its selective character, turning to deterministic points of view (see also Raup, 1994).

Finally, he saw that processes acting in evolution were inferred many times from patterns shown by the fossil record. This means, for instance, that long-life diversified clades (pattern) have a high evolutionary success because of this single reason. Immediately, it is concluded that this is due to the action of natural selection (process); i.e., the common characters shared by the members of the clade have overcome all the environmental challenges, and thus, they are successful. However, this would be a tautological statement that, in addition, invokes a deterministic explanation. Thus, he proposed an alternative: diversification and duration of clades could be generated stochastically (e. g. Raup et al., 1973). This has to do with the Markovian character of evolution. That is, each step depends partly on the previous one, albeit the last step has equal probabilities for its alternatives of speciation and extinction. 
These last statements designed a research programme on the random features in evolution. He included as evolution both origination and extinction processes from its perception through the fossil record (macroevolution), whose structure must also be interpreted. However, its position in this non-deterministic conception didn't deny the value deterministic explanations but it was a methodological caution against tautological reasoning, as I shall show.

\subsection{The structure of the fossil record and its consequences}

In the first chapter of Raup \& Stanley (1971) textbook, it is said that the current biotic diversity wouldn't differ very much from that of the Cambrian period. This is the opposite to the general opinion by which there was a steady increase of diversity during the Phanerozoic inferred from the fossil raw data. This increasing diversity would be an artefact because of the characteristics of the fossil record (smaller outcrop surfaces and sedimentary volume of older rocks as compared with more recent ones). However, I think that the presentation of this topic was due to Raup, since he dealt with it in successive papers without the collaboration of Stanley, his colleague.

The questions formulated by Raup on the fossil record were not new; he changed, however, the focus on them and proposed a new way to address these problems. His proposal might be summarized by saying that the structure of the fossil record raises sampling problems, because there are a large amount of fossils to be discovered or, in other words, we need to get new samples from the record. Other authors had already observed that the sedimentary marine record changed in quality through time in terms of sedimentary volume, with a climax at Devonian times (twice than in the Cambrian), a declining magnitude until the Triassic, and a dramatic expansion for the Tertiary after a slow and progressive improvement during the Mesozoic. The various patterns of diversity for the fossil marine invertebrates (at genus and family levels), published until that moment, paralleled the same pattern in time (Raup, 1972b). Thus, changes in quality of the sedimentary record were roughly correlated to changes in the diversity pattern (Fig. 3). This involves a sampling bias inducing errors.

Raup (1972b) exemplified the sampling approach in terms of a tray with cells and balls thrown at random on them. These balls fall on the tray and can occupy cells irrespective of the cells previously occupied. Such approach raises the question about the probability of occupying the cells by balls, and the next question is about the waiting times for occupancy of cells, which is a function of the number of cells $m$. Cells, for him, are equivalent to the total number of taxa available awaiting to be discovered by palaeontologists, and each ball is a fossil; its

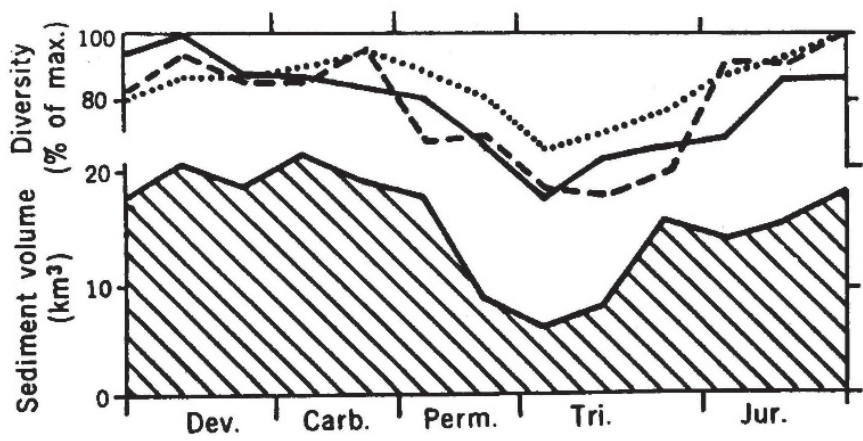

Figure 3. This graphic describes the quality of the sedimentary record throughout time, as measured in $\mathrm{km}^{3}$ (estimated volume of marine and lagoonal clastic and carbonate sediments) and diversity in terms of families and genera of well-skeletonized marine invertebrates, from different sources (solid line and dashed line are two different compilations for families, and dotted line for genera). From Raup (1972b), with permission of Science.

identification would lead to place each ball in a cell (identified taxon). The number of cells increases, in the taxonomical hierarchy, from the highest level (phylum) to the lowest level (species), due to the enclosing structure of any hierarchical structure. There is, however, a discontinuity in the numbers of phyla, classes and orders, on the one hand, and of families, genera and species, on the other hand. Thus, waiting times to know the numbers of phyla are short since there are few phyla or classes compared with families, genera or species. A broad geographic sampling can yield a reliable sample for phyla. On the contrary, family, genus and species are taxonomic levels with larger and increasing values of $m$. The sampling effort in terms of sampled geographic areas will be increasing as the taxonomic level lowers in the taxonomic hierarchy. This is perhaps one of the first times he introduced probability in processing fossil record data. He carried out theoretical simulations for different values of $m$. Applying the same concepts to the ammonoids of the Meekoceras zone (Triassic), he reproduced a similar pattern for genera, families and superfamilies.

He added other seven sources of error affecting diversity data, as range charts (overestimated diversity in non-fossiliferous intervals), or the influence of 'extant' records (the late Mesozoic and Cenozoic, with many extant taxa; that is, they are biased toward larger diversity and fewer extinctions than the Palaeozoic and the early and middle Mesozoic). With these premises, Raup analysed again the diversity patterns of marine invertebrates able to fossilize easily because of the nature of their mineralised skeletons. He mainly based his discussion on Valentine's (1969) analysis. Valentine worked with raw data from 
several sources taking only into account the bias produced by the differential preservation of taxa (well-skeletonized versus soft-bodied animals), and considering only the record of the former. He concluded some results, all of them coherent with plausible current ideas at that time. However, Valentine's patterns showed a strong coincidence with those predicted by Raup for higher levels of the taxonomic hierarchy (class, order) against the lower levels (family, genus, species). The latter showed a strong increase in numbers after the Permo-Triassic mass extinction, whereas the former became more or less stable after this event. Moreover, the observed patterns were similar to those predicted by the different kinds of biases, mainly the improving of the record with time and the increasing of diversity as the Recent is approached (influence of the extant records). Nevertheless, he recognized that the impact of these biases affecting the fossil record was not quantified, and evolutionary and ecological explanations could become also valid alternatives.

Therefore, the observed diversity of the wellskeletonized groups shows patterns due to the predicted biasing effects, and this is compatible with a maximum of diversity in the Palaeozoic. In order to test for the plausibility of this model, he simulated, from 2000 hypothetical species distributed into 100 genera, random originations and extinctions by choosing random numbers, and plotting them on a range chart. The obtained curves would represent diversity before the biases had operated, and thus, without contradiction.

Due to these problems, he proposed the use of the rarefaction techniques utilized by benthic ecologists, who had similar problems when dealing with small samples (Raup, 1975a). Raup applied these techniques to the increasing number of families of post-Palaeozoic echinoids (7911 species). He validated the technique, since the increasing number of families of this group until the Recent is not an artefact because it is not explained only in terms of increasing number of preserved species. In addition, he confirmed his early position (Raup, 1972b) in two papers about species diversity during the Phanerozoic, a paper dealing with diversity tabulation (Raup, 1976a) and another presenting an interpretation (Raup, 1976b) as due to the significant correlation between volume and exposed area of sedimentary rocks, and species diversity. Again, increasing species diversity during the Phanerozoic confirmed its artefactual character.

\subsection{The stochastic metaphor of evolution}

Raup headed several papers, or participated in them, about phylogenies based on equilibrium population models. These papers assumed only the monophyly of clades and the evolutionary equilibrium in terms of equal probabilities of speciation $(\lambda)$ and extinction $(\mu)$ in a Markovian process (see Raup et al., 1973; Raup, 1977; Gould et al., 1977). With these premises, phylogenies were simulated with the MBL computer programme, developed at the Marine Biological Laboratory (Woods Hole). These simulated phylogenies consisted of clearly differentiated clades.

In these papers, it is not generally assumed any selective or adaptive constraint. An explicit introduction of ecological constraints is that of accepting an optimum number of lineages coexisting in time; this means the full occupation of an adaptive zone, which becomes saturated. If diversity is larger or smaller than a conventionally specified optimum, $\mu$ or $\lambda$ increase respectively. As the optimum is reached, $\lambda$ equals $\mu$ again. From these specifications, Gould et al. (1977) defined two strategies for the MBL programme: 'freely floating' (FF; without optimum), and 'damped equilibrium' (DE; with optimum).

Phylogenies built under such assumptions show apparent similarity in diversity with real evolutionary patterns, such as in reptiles (Raup et al., 1973). However, these stochastic patterns don't reflect real events such as mass extinctions, which affected reptiles at the end of the Cretaceous. They explain neither the existence of living fossils nor rapid radiations. The purpose of these simulations was to compare stochastic clades with real clades, and to distinguish those features that can be produced by chance from those generated in a deterministic way, such as a meteorite impact with catastrophic effects leading directly to the simultaneous extinction of many lineages. However, the different evolutionary events result from multiple causes, in such a way that it is difficult to predict them for a given time; this is because each cause at the time of the event has a specific probability (Raup et al., 1973), which we ignore. Since it is problematic to recognize true randomness, it is better to use the term 'pseudorandomness' in order to characterize extinction or speciation events (Raup, 1977). In general, predictions can only be formulated statistically. This is a nomothetic attitude; i.e. looking for common features in very disparate phenomena (Raup et al., 1973; Gould, 1980). The general attitude of many palaeontologists was to look for specific causes of specific events, for instance, why did species $X$ become extinct at moment $Y$ ? Each specific event and its cause is an idiographic aspect. The purpose of these papers was to develop a nomothetic palaeontology.

Another feature outlined in Raup et al. (1973), and extensively developed in Gould et al. (1977), is the question of clade diversity (CD), as measured in terms of number of taxa in time. This was done initially for lineages, but we can assess the diversity in terms of genera within a clade (family or order), or families within a class. Fluctuations of diversity generate symmetrical diagrams, a very frequent representation of palaeontological data. These diagrams seem to show characteristics of order. This is not strange since evolution is a Markovian process in which contractions (expansions) of diversity in a clade 
seem to show coincidence with expansions (contractions) in another that apparently suggest competition.

In order to understand how CD behaves in time, Gould et al. (1977) adopting the aforementioned two strategies for the MBL programme ['freely floating' (FF) and 'damped equilibrium' (DE)] defined five clade statistics (CS): size $=$ SIZE, or total diversity; duration $=$ DUR, or time span of the clade; centre of gravity $=\mathrm{CG}$, or relative position in time of mean clade diversity; maximum diversity = MAX DIV, or number of lineages at the moment in which the clade is widest, and uniformity = UNI, or extent of fluctuation in diversity. CG and UNI are adimensional parameters varying between 0 and 1 . The remaining parameters are dimensional. These parameters change in function of the equilibrium probability $(\lambda=\mu)$ values in simulated clades. For example, $\mathrm{CG}$ has positions $<0.5$ for FF and probabilities $(\lambda=\mu)<0.1$ and UNI decreases considerably for FF and DE with increasing probabilities of speciation and extinction. A low position of CG means a rapid initial diversification and high values for UNI mean little fluctuations of diversity throughout time, without excessive originations or extinctions; the reverse situation consists of large amounts of diversity followed by dramatic falls. These CSs are key for comparing random clades with real ones. In general, the authors found strong similarities between random and real clades. Many of these simulated clades became extinct (E) before the 'recent' moment of the simulated geologic time, just as it occurs for real life history. Thus, the comparative analysis of random and real clades distinguished clades $\mathrm{E}$ from alive clades (A), arriving at the Recent (real or simulated). The programme started from two basic premises: 1) it was "untaxonbounded", that is, facts occur independently of any favorable or unfavorable trait of the different taxa involved (no preferential speciation or extinction rates among taxa), and 2) it was "untimebounded", that is, there were not specific times for preferential speciation or extinction phenomena). "Untaxonbounded" and "untimebounded" are terms coined by the authors.

However, they found several cases in which strong departures between random and real clades were observed. An example is that of high taxonomical separation in clades. Diversity within a clade can be measured as number of species. However, a clade can be a phylum, class, order or family. Many times, its diversity is expressed as number of genera or species. Taxonomical separation is defined according to the level in the taxonomical hierarchy; genera in classes have a larger taxonomical separation than genera in families. Real clades of large taxonomical separation show very low values of UNI $(<0.5)$ in average, but simulated clades under the $\mathrm{DE}$ assumption averaged UNI $>0.5$. There are several possibilities for this result that don't reject the randomness hypothesis. However, genera in the amphibian (UNI $=0.191)$ or mammal classes $(\mathrm{UNI}=0.299)$ would show 'good' diversification times (Carboniferous for amphibians, and Tertiary for mammals). Competition by the rising of reptiles affected the amphibians since the Permian. During the Mesozoic, dinosaurs and other reptilian groups constrained amphibians to a minimal generic diversity until the extinction of the former at the $\mathrm{K} / \mathrm{Pg}$ mass extinction. They not only constrained amphibians but mammals as well during the Mesozoic. After the K/Pg extinction, amphibians diversified again, but they recovered only their diversity level during the Carboniferous. This was not the case of mammals, whose diversity increased dramatically during the Tertiary.

A last research explored the morphological changes associated to phylogenies. Raup \& Gould (1974; but see also Raup, 1977) built a stochastic model of phylogeny under the same premises (monophyly, punctuated equilibria and equal probabilities of branching and extinction). They wanted to obtain a picture of morphological change in entities in which ten characters evolved independently following a stochastic way. The manner to achieve this goal was as follows: at each branching point, each character can undergo change according to a new set of probabilities, and the simulated morphologies would change regardless of the cladistic part of the programme. Changes in character could attain positive, zero or negative values starting from a conventional morphology defined as $(0,0,0,0,0,0,0,0,0,0)$ for the ten characters. At each branching point, each character could add a positive or negative unit, with probabilities $\mathrm{p}_{+1}$ and $\mathrm{p}_{-1}$, respectively, or could add nothing, with probability $\mathrm{p}_{0}$. The required condition for stochastic change would be $\mathrm{p}_{+1}=\mathrm{p}_{-1}=\mathrm{p}_{0}$.

The interest in this simulation for Raup and Gould was not a reproduction of nature but to observe if apparent directional changes arise. In the fossil record, directional changes, such as evolutionary trends, seem to be apparent. Correlation of characters and morphological coherence in taxonomic groups appear as well. Palaeontologists interpreted them as synonymous of uni-directional causes or order. In general, they are associated to evolutionary processes, and many of these features would be due to sustained uni-directional natural selection. Raup \& Gould (1974) concluded that the simulation, because of its Markovian character, produced very similar results simply by chance. An image was graphically produced with drawings called 'triloboids' (see also Raup, 1977). Since natural selection promotes directional changes in efficiency, arguments for its action would have to be found in functional analysis, but not in the crude directionality of the pattern.

\subsection{Extinction, probabilities and time series}

Raup began to be interested on extinction in the seventies. He paid attention to estimates of extinction rates in 
background extinctions in two papers. In the first (Raup, 1975b), he referred to the attempts of Van Valen (1973) and his well-known evolutionary law about the stochastically constant extinction rate for ecologically homogeneous taxa. He criticized several features of the Van Valen's treatment of data, based on taxonomic survivorship. The next paper (Raup, 1978b), he imported a new technique based on insurance actuary for the study of survivorship: cohort analysis. A cohort consists of the individuals born in a specific year. Many of these individuals will die in each of the following years. Their number in each year allows drawing a survivorship curve relating age to mortality. He extrapolated this technique to taxa in geologic time, for instance, to genera, and obtained several interesting results such as the similarity of patterns throughout the Phanerozoic. A variant of this technique was the use of pseudocohorts (Raup, 1986a). Pseudocohorts differ from cohorts in which the starting collective consists of all the living 'individuals' in a specified moment of geologic time. This technique reflects the episodic character (episodic extinction) of the apparently continuous background extinction. In this case, mass extinctions appear as very intense episodes (see also Raup, 1987). All these results derive from a mathematical treatment of data from the fossil record.

Another question he dealt with was the extinction of higher taxa (Raup, 1978a) or, more specifically, if extinction is due to bad luck (Galtonian extinction) or bad genes (Raup, 1981b). Raup (1978a) took the model of human family surnames and how they disappear in our societies. He paid attention to the stochastic character of their elimination, and took into account that geneticists had designed mathematical models in order to deal with the evolution of neutral genes, because these last ones and surnames share their neutral selectivity as characters. Again, he compared random clades with real clades. If departures from the stochastic hypothesis are significant, we can accept that there could be traits driving taxa to extinction. Thus, family or higher taxonomic levels in the fossil record are similar to human family surnames since there are many monotypic taxa (human families with few members) and few radiating taxa (human families with large offspring). The former are more prone to extinction than the latter. Raup (1981b) applied probabilistic formulae derived from mortality in populations coming from the homogeneous birth-death model applied by Yule, who conceived speciation and extinction as random events with constant probabilities $\lambda$ and $\mu$ (homogeneous process), which are not necessarily equal. Thus, the probability of extinction depends on $\mu$, or on $\lambda-\mu$, if $\lambda \neq \mu$, the duration of the group, and the initial number of lineages. For a mean extinction rate $\mu=0.09$ (Phanerozoic invertebrates) and $\lambda$ $=\mu$, this probability gets lower as the initial number gets larger. So, trilobites (6,000 lineages at the lower Cambrian, and a time span of $350 \mathrm{Ma}$ in 1981) had an almost null probability to become extinct at the end of the Permian by simple bad luck. He synthesized many of these procedures in Raup (1985).

Mass extinctions received an important treatment in Raup \& Sepkoski (1982). They carried out a statistical analysis after a compilation of fossil data from both marine invertebrates and vertebrates at the family level. Most families (87\%) were followed at the stratigraphic stage level, whose mean duration was 7.4 Ma, and the remaining families (13\%), at the series level (mean duration, $20 \mathrm{Ma}$ ). They concluded that four moments of geologic time showed significant statistical departures $(p<0.01)$ from background extinction levels: Ordovician (Ashgillian), Permian (Guadalupian and Dzhulfian), Triassic (Norian) and Cretaceous (Maestrichtian). However, large extinctions in the late Devonian had no significant departure. Background extinction rates have seemingly diminished since the Cambrian times. This is coherent with a prediction of increasing fitness during the Phanerozoic. Mass extinctions were previously known, and attributed lastly to meteorite impacts. In addition, they seemed sparse at random over the geologic time. Therefore, Raup (1981a) considered them a specific case of statistics of rare events. At that stage of the research, the use of a Poisson process approach showed that the hypothesis of a random distribution for mass extinctions in the Phanerozoic cannot be rejected. Later, this landscape was going to change sharply.

David M. Raup, jointly with John Sepkoski (Raup \& Sepkoski, 1984, 1986), addressed the problem from the perspective of extinction as a non-continuous, nonhomogeneous process, in which there were intervals with almost null risk of extinction alternating with events of more or less intense extinction and short duration (episodic extinctions; Fig. 4) (Raup, 1986a, 1987). Raup \& Sepkoski (1984) started from a compiled database of marine families (vertebrates, invertebrates and protozoans) by Sepkoski, and analysed the interval, from the Late Permian to the Tertiary $(253 \mathrm{Ma})$. They decided to use as extinction rate the percentage of extinct families from the total present families in a stage. They found that numbers of extinctions have an almost null correlation with stage duration, an indirect support to the episodic extinction hypothesis. When percentage of extinction was plotted against geologic time, data showed qualitatively an apparent periodicity. However, the authors were not happy with this appearance. Other authors (Fischer, 1981) had seen the possibility of a stressed biosphere because of climatic oscillation due to several causes originated directly from the Earth (its orbital perturbation, patterns in mantle convection, and so on), with a rhythm around $30 \mathrm{Ma}$. Thus, they looked for quantitative validation of the approximate periodic pattern. Their method was based on Fourier analysis and autocorrelation (correlogram) for time series (Fig. 5). From these analyses, data seem well fitted to the periodicity 


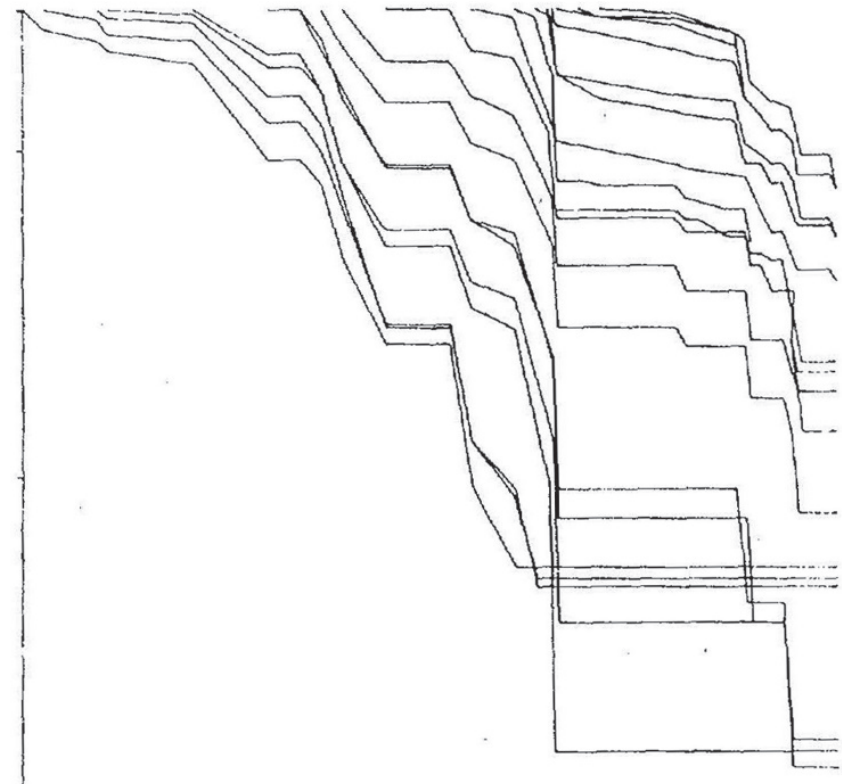

(Samples)

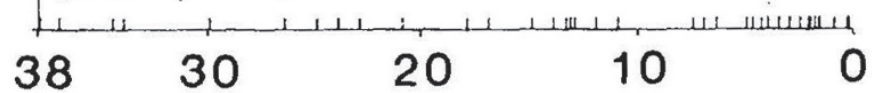

Figure 4. Episodic extinction. Pseudocohorts of Tertiary planktonic foraminifers monitored with a refined time scale show an irregular, and punctuated pattern when the points of each one of them are connected with a broken line. This is the reverse situation of Van Valen's law with its continuous appearance. Horizontal segments alternate with more or less sharp extinction phenomena suggesting their episodic character. From Raup (1986a), with permission of Science.

hypothesis, with a rhythm of $26 \mathrm{Ma}$, albeit a conclusive statement was not possible to reach by several reasons. Therefore, they performed several nonparametric tests, and the conclusion was the same, but this was based on the reliability of Harland's time scale (Harland et al., 1982). Since two mass extinctions were conclusively associated to meteorite impacts (Late Cretaceous and late Eocene), the causes for large extinctions should then be looked at in extraterrestrial influences, because the authors didn't conceive of periodicity intrinsic to earthbound processes, biotic or purely physical ones. Periodicity, however, characterizes astronomical events. A more refined analysis (Raup \& Sepkoski, 1986) was performed with genera, resulting in a support of $26 \mathrm{Ma}$ cycle, and asked for new evidences in order to confirm it. Many cases of documented meteorite impacts and extinction events (extinction-impact pairs) raised doubts about their correct interpretation (Raup, 1988), which suggested the need of a more coordinate research in astronomy and in palaeontology,

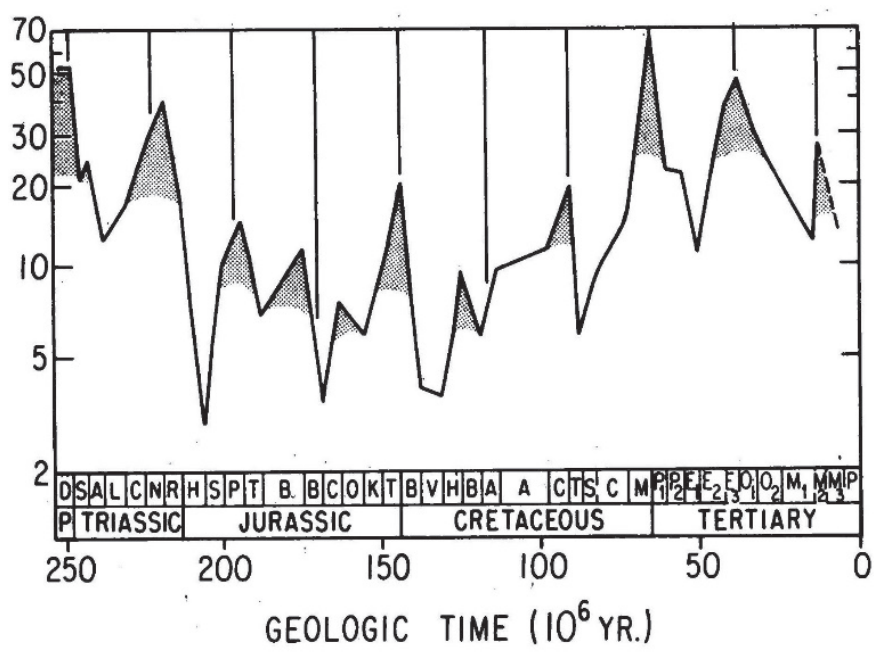

Figure 5. Periodicity of extinction over the past $250 \mathrm{Ma}$ (Harland timescale). Stratigraphic stages identified by letter codes (bottom). The best-fit 26-ma cycle is placed along the top as vertical lines. From Raup \& Sepkoski (1984), with permission of PNAS.

as well as a more precise localization of extinction events and impacts (see also Raup, 1987, for a general comment involving another astronomical periodicity with lower cyclicity periods: Milankovitch cycles).

A last derivation of these deterministic approaches, irrespective of possible periodicities, was that of the monotonic and continuous distribution of frequencies for extinction intensities, as depicted by Sepkoski (1989). Extinction intensity is negatively related to frequency; i.e., low intensities are very frequent whereas the highest intensities are rare. This has very low probability to be due to chance (Raup, 1996). Therefore, the Lyell-Darwin model (there is no mass extinction, only progressive extinction by pure competition with improved forms) is invalidated, because there is a continuous spectrum of intensities, from the lowest to the highest. Since this is not due to chance, a model is needed, because pulses of extinction 'must be connected in some way' (common factors, such as ecological interdependence or shared physical stress). Raup didn't propose, however, a new model for extinction but a mathematical framework, the kill curve (Raup, 1991a), on which we could work.

Many of these questions about extinctions (bad genes or bad luck, or extraterrestial causes in general) were popularized by him in two books (Raup, 1986b, 1991b), an important contribution to communicate our science to non-specialized people beyond mere anecdotes. 


\section{DISCUSSION AND CONCLUSIONS}

David M. Raup was an outstanding member of the generation that contributed to formulate a new paradigm for palaeontology, conceived essentially as palaeobiology. The American journal Paleobiology, whose first issue appeared in 1975, was a first step, albeit many other prestigious European and American journals published abundant palaeobiological papers for several years. This point of view was far from the consolidated activities of many palaeontologists, who had fallen into routines with poor conceptual backgrounds. Several names are more or less constant in this generation, basically David M. Raup, Stephen J. Gould, Thomas J.M. Schopf and John J. Sepkoski, who were still young people at that time, as well as the ecologist Daniel S. Simberloff, who joined them. They signed collectively some of the essential papers published during the seventies as true manifests (e.g. Raup et al., 1973). Later, the majority of papers were signed by a single author, as it is the case of Raup.

Raup worked as the mathematical and computational minded-man of the group. In his youth, he was refractory to these methods, in which Everett Olson was a pioneer. However, the sound scientific environment around the young David influenced him in such a way that he changed his early points of view, focused on traditional systematic and biostratigraphic approaches. Gould contributed, most likely, to the spirit of the group with his epistemological and historical standpoint on evolution. I think that the contribution of Gould in Raup \& Gould (1974) and Gould et al. (1977) is the distinction between idiographic and nomothetic aspects in historical sciences as applied to palaeobiology, which he developed later (Gould, 1980). Many of these papers have adhered to the idea of Eldredge \& Gould (1972) of punctuated equilibria, by which evolution is concentrated in punctuational speciation events in a static framework (morphological stasis of lineages), as an alternative to the more traditional view of phyletic gradualism embedded in the modern synthesis.

As highlighted by Foote \& Miller (2016), David M. Raup devoted almost twenty years of his productive life to morphology. I have tried to remark the importance of his work in this field. In addition to his original treatment of theoretical morphology, Raup was enthusiastic with the new perspective raised by Adolf Seilacher in Germany, his Konstruktions-Morphologie. Perhaps, the strong influence from Ernst Mayr favoured his early adaptationist ideas. However, when he studied the orientation of the $c$-axes in the apical system plates of echinoids before 1970, he confirmed that their orientations are laid in the larval stage, before metamorphosis, and thus, they have nothing to do with a possible adaptive advantage in adults. Therefore, he probably had a predisposition to admit non-adaptive approaches like those of Seilacher, and advocated them in Raup (1972a).
Raup dealt with many of the traditional fields of palaeontology: the fossil record and its characteristics, as well as its capability to yield a more or less real vision of the history of life on Earth. His work focussed on morphology as the primary source of data for palaeobiological interpretation, and last but not least, on evolution including extinction as a relevant feature of the evolutionary process.

Since he adopted the notion of punctuated equilibria, he extended catastrophist viewpoints not only to extinction but also to evolution in general. He showed that background extinction, which appears to us as a more or less continuous process, really obeys a law similar to that of punctuated equilibria: relatively long phases with very low extinction rates alternate with short episodes of higher (catastrophic) extinction rates, including those characterizing mass extinctions. In reference to evolution, although it shows order evidenced by directional change, this order cannot be attributed to directional causes by the only observation of pattern because it may be also generated by random change due to the Markovian character of the processes involved. Thus, generation of order by chance must be always verified. Extinction events can also occur stochastically, but new data can refute the hypothesis of chance, as in the case of more refined data of marine families and genera over the Phanerozoic, which seem to confirm a periodicity by several mathematical evidences based on Fourier analysis or autocorrelation analysis. If trends by adaptive improvement are considered as another cause, it must be tested independently of pattern; in the example, functional morphology supplies arguments regardless of the directed pattern. For the solution of all these problems, he showed a great imagination since he was able to import methods and techniques coming from fields far from palaeontology in general, such as insurance actuary.

Many of these new topics had to be communicated in a more systematic manner to the future palaeontologists, in order to provide them with this new way to see our science. Then Raup collaborated with Steven M. Stanley to write his seminal book Principles of Paleontology. At that time, the paradigm had made his way to be communicated in terms of a textbook of palaeontology with its two editions $(1971,1978)$. This was not the only book wrote by him; he contributed to popularize science by means of other two books about extinction as a fundamental process in the biosphere: Extinction: Bad Genes or Bad Luck? and The Nemesis Affair: A Story of the Death of Dinosaurs and the Ways of Science

His work was an example for future palaeontologists, and we thank him for the problems that he faced, his original and imaginative solutions, and above all, the multiple problems suggested by his approaches to palaeobiology. Our best homage to David is recognizing, remembering and analyzing his seminal contributions, and advancing in the solutions of the problems and open questions that his work rendered for us. 


\section{ACKNOWLEDGMENTS}

I thank Drs. Paul Palmqvist (Universidad de Málaga), an anonymous reviewer, Diego Rasskin-Gutman (Universitat de València), and Julio Aguirre (Universidad de Granada) for their comments and suggestions. Dr. Jordi Martinell (Universitat de Barcelona) has kindly provided the picture of Fig. 1. This paper has been supported by the project CGL2014-52662-P and CGL2016-80975-P of the Spanish Ministerio de Economía y Competitividad.

\section{REFERENCES}

Ager, D.V. 1963. Principles of Paleoecology. McGraw-Hill, New York.

Alberch, P. 1980. Ontogenesis and morphological diversification. American Zoologist, 20, 653-667.

Alberch, P. 1982. Developmental constraints in evolutionary processes. In: Evolution and Development (ed. Bonner, J.T.). Dahlem Konferenzen 1982. Springer Verlag, Berlin, 313-332.

Alberch, P., Gould, S.J., Oster, G.F. \& Wake, D.B. 1979. Size and shape in ontogeny and phylogeny. Paleobiology, 5, 296-317.

Alvarez, L.W., Alvarez, W., Asaro, F. \& Michel, H.V. 1980. Extraterrestrial cause for the Cretaceous-Tertiary extinction. Science, 208, 1095-1108.

Beerbower, J.R. 1960. Search for the Past. An Introduction to Paleontology. Englewood Cliffs, New Jersey.

Beerbower, J.R. \& Jordan, D. 1969. Application of information theory to paleontologic problems: taxonomic diversity. Journal of Paleontology, 43, 1184-1198.

Bell, M.A. 1998. Everett C. Olson (November 6, 1910-November 27, 1993). Biographical Memoir, National Academy of Sciences. National Academic Press, Washington.

Collinson, C. 1960. Review of search for the past, by James R. Beerbower. Science, 132, 666.

Crusafont, M. \& Truyols, J. 1956. A biometric study of the evolution of fissiped carnivores. Evolution, 10, 314-332.

Crusafont, M. \& Truyols, J. 1957. Estudios masterométricos en la evolución de los fisípedos. Boletín del Instituto Geológico y Minero de España, 68, 83-224.

Crusafont, M. \& Truyols, J. 1958. A quantitative study of stasigenesis in fissiped carnivores. Nature, 181, 289-290.

Crusafont, M., Meléndez, B. \& Aguirre, E. (eds) 1966. La Evolución. Biblioteca de Autores Cristianos, Madrid.

Darwin, C. 1859. On the Origin of Species. Facsimile of the first edition, 1964. Harvard University Press, Cambridge, Massachusetts.

De Renzi, M. 1981. Some philosophical questions about paleontology and their practical consequences. In: Concept and Method in Paleontology (ed. Martinell, J.), Acta Geológica Hispánica, 16, 7-23.

De Renzi, M. 2005. Palaeontology as a science: going beyond mechanical routines and search for treasures. In:
Miscelánea Paleontológica (eds Meléndez, G., MartínezPérez, C., Ros, S., Botella, H. \& Plasencia, P.). SEPAZ, $6,3-45$.

De Renzi, M. 2009. Developmental and historical patterns at the cross-roads in the work of Pere Alberch. In: Pere Alberch: The Creative Trajectory of an Evo-Devo Biologist (eds Rasskin Gutman, D. \& De Renzi, M.). Institut d'Estudis Catalans \& Universitat de València, València, 45-66.

Efremov, J.A. 1940. Taphonomy: new branch of paleontology. Pan-American Geologist, 74, 81-93.

Efremov, J.A. 1950. Taphonomie et annales géologiques. Annales du Centre d'Etudes et de Documentation Paléontologiques, 4 (1953), 1-196.

Eldredge, N. \& Gould, S.J. 1972. Punctuated equilibria: an alternative to phyletic gradualism. In: Models in Paleobiology (ed. Schopf, T.J.M.). Freeman, Cooper \& Company, San Francisco, California, 82-115.

Erwin, D.H. 2015. David M. Raup (1933-2015): Palaeobiologist who pioneered mathematical modelling of mass extinctions. Nature, 524, 36.

Fischer, A.G. 1981. Climatic oscillations in the biosphere. In: Biotic Crises in Ecological and Evolutionary Time (ed. Nitecki, M.H.). Academic Press, New York, 103-131.

Foote, M. \& Miller, A.I. 2016. The contributions of David Malcolm Raup (24 April 1933-9 July 2015). Paleobiology, 42, 172-183.

Gould, S.J. 1971. Tübingen meeting on form. Journal of Paleontology, 45, 1042-1043.

Gould, S.J. 1977. Ontogeny and Phylogeny. The Belknap Press at the Harvard University Press, Cambridge, Massachusetts.

Gould, S.J. 1980. The promise of paleobiology as a nomothetic, evolutionary discipline. Paleobiology, 6, 96-118.

Gould, S.J., Raup, D.M., Sepkoski, J.J., Jr., Schopf, T.J.M. \& Simberlof, D.S. 1977. The shape of evolution: a comparison of real and random clades. Paleobiology, 3, 23-40.

Grene, M. 1958a. Two evolutionary theories (I). The British Journal for the Philosophy of Science, 9, 110-127.

Grene, M. 1958b. Two evolutionary theories (II). The British Journal for the Philosophy of Science, 9, 185-193.

Harland, W.B., Cox, A.V., Llewellyn, P.G., Pickton, C.A.G., Smith, A.G. \& Walters, R. 1982. A Geologic Time Scale. Cambridge University Press, Cambridge, England.

Hatfield, C.G. \& Camp, M.J. 1970. Mass extinctions correlated with periodic galactic events. Geological Society of America Bulletin, 81, 911-914.

Imbrie, J. \& Newell, N.D. (eds) 1964. Approaches to Paleoecology. John Wiley and Sons, Inc., New York.

Kuhn, T.S. 1971. The Structure of Scientific Revolutions. $2^{\text {nd }}$ edition. The University of Chicago Press, Chicago.

Lawrence, D.R. 1971. The nature and structure of paleoecology. Journal of Paleontology, 45, 593-607.

Lipps, J.H. 1981. What, if anything, is micropaleontology? Paleobiology, 7, 167-199.

Lyell, C. 1832. Principles of Geology: An Attempt to Explain the Former Changes of the Earth's Surface, by Reference to Causes Now in Operation, vol. 2. John Murray, London. 
Manceñido, M.O. \& Damborenea, S.E. 2003. Alcide d'Orbigny: A harbinger of the Chicago approach a century and half ago? Revista Técnica de Yacimientos Petroliferos Fiscales Bolivianos, 21, 245-250.

Maynard-Smith, J., Burian, R.C., Kauffman, S., Alberch, P., Campbell, J., Goodwin, B., Lande, R., Raup, D. \& Wolpert, L. 1985. Developmental constraints in evolution. The Quarterly Review of Biology, 60, 265-287.

McKinney, F.K. \& Raup, D.M. 1982. A turn in the right direction: simulation of erect spiral growth in the bryozoans Archimedes and Bugula. Paleobiology, 8, 101-112.

Newell, N.D. 1981. Memorial to Bernhard Kummel, 19191980. The Gological Society of America Memorials, 12, $1-4$.

Olson, E.C. \& Miller, R.L. 1958. Morphological Integration. Reprint 1999. The University of Chicago Press, Chicago.

Palmqvist, P. 2016. Los antecedentes del libro "La Evolución": la masterometría de Crusafont y Truyols, los "Cursillos Internacionales de Paleontología de Sabadell” (1952-1958) y el desarrollo de la paleontología evolutiva en España. Actas de las XXXII Jornadas de la Sociedad Española de Paleontología. Cuadernos del Museo Geominero, 20, 533-538.

Rafferty, J.P. 2015. David Malcolm Raup, American paleontologist. http://www.britannica.com/biography/ David-M-Raup.

Raup, D.M. 1959. Crystallography of echinoid calcite. The Journal of Geology, 67, 661-674.

Raup, D.M. 1961. The geometry of coiling in gastropods. PNAS, 47, 602-609.

Raup, D.M. 1962. Computer as aid in describing form in gastropod shells. Science, 138, 150-152.

Raup, D.M. 1965. Crystal orientations in the echinoid apical system. Journal of Paleontology, 39, 934-951.

Raup, D.M. 1966. Geometric analysis of shell coiling: General problems. Journal of Paleontology, 40, 1178-1190.

Raup, D.M. 1967. Geometric analysis of shell coiling: Coiling in ammonoids. Journal of Paleontology, 41, 43-65.

Raup, D.M. 1972a. Approaches to morphologic analysis. In: Models in Paleobiology (ed. Schopf, T.J.M.). Freeman, Cooper \& Company, San Francisco, 28-44.

Raup, D.M. 1972b. Taxonomic diversity during the Phanerozoic. Science, 177, 1065-1071.

Raup, D.M. 1975a. Taxonomic diversity estimation using rarefaction. Paleobiology, 1, 333-342.

Raup, D.M. 1975b. Taxonomic survivorship curves and Van Valen's Law. Paleobiology, 1, 82-96.

Raup, D.M. 1976a. Species diversity in the Phanerozoic: a tabulation. Paleobiology, 2, 279-288.

Raup, D.M. 1976b. Species diversity in the Phanerozoic: an interpretation. Paleobiology, 2, 289-297.

Raup, D.M. 1977. Stochastic models in evolutionary palaeontology. In: Patterns of Evolution, as Ilustrated by the Fossil Record (ed. Hallam, A.). Elsevier Scientific Publishing Company, Amsterdam, 59-78.

Raup, D.M. 1978a. Approaches to the extinction problem. Journal of Paleontology, 52, 517-523.
Raup, D.M. 1978b. Cohort analysis of generic survivorship. Paleobiology, 4, 1-15.

Raup, D.M. 1981a. Introduction: What is a crisis? In: Biotic Crises in Ecological and Evolutionary Time (ed. Nitecki, M.H.). Academic Press, New York, 1-12.

Raup, D.M. 1981b. Extinction: bad genes or bad luck? In: Concept and Method in Paleontology (ed. Martinell, J.). Acta Geológica Hispánica, 16, 25-33.

Raup, D.M. 1985. Mathematical models of cladogenesis. Paleobiology, 11, 42-52.

Raup, D.M. 1986a. Biological extinction in Earth history. Science, 231, 1528-1533.

Raup, D.M. 1986b. The Nemesis Affair: a Story of the Death of Dinosaurs and the Ways of Science. [Spanish translation 1990]. Alianza Editorial, Madrid

Raup, D.M. 1987. Mass extinction: a commentary. Palaeontology, 30, 1-13.

Raup, D.M. 1988. The role of extraterrestrial phenomena in evolution. Revista Española de Paleontología, $\mathrm{n}^{\circ}$ extraordinario, 99-106.

Raup, D.M. 1991a. A kill curve for Phanerozoic marine species. Paleobiology, 17, 37-46.

Raup, D.M. 1991b. Extinction: Bad Genes or Bad Luck? W.W. Norton \& Company, New York.

Raup, D.M. 1994. The role of extinction in evolution. PNAS, 91, 6758-6763.

Raup, D.M. 1996. Extinction models. In: Evolutionary Paleobiology (eds Jablonski, D., Erwin, D.H. \& Lipps, J.H.). The University of Chicago Press, Chicago, 419-433.

Raup, D.M. \& Gould, S.J. 1974. Stochastic simulation and evolution of morphology - Towards a nomothetic paleontology. Systematic Zoology, 23, 305-322.

Raup, D.M. \& Graus, R.R. 1972. General equations for volume and surface area of a logarithmic coiled shell. Mathematical Geology, 4, 307-316.

Raup, D.M. \& Michelson, A. 1965. Theoretical morphology of the coiled shell. Science, 147,1294-1295.

Raup, D.M. \& Seilacher, A. 1969. Fossil foraging behavior: Computer Simulation. Science, 166, 994-995.

Raup, D.M. \& Sepkoski, J.J., Jr. 1982. Mass extinctions in the marine fossil record. Science, 215, 1501-1502.

Raup, D.M. \& Sepkoski, J.J., Jr. 1984. Periodicity of extinctions in the geologic past. PNAS, 81, 801-805.

Raup, D.M. \& Sepkoski, J.J., Jr. 1986. Periodic extinction of families and genera. Science, 231, 833-836.

Raup, D.M. \& Stanley, S.M. 1971. Principles of Paleontology. W.H. Freeman and Company, San Francisco.

Raup, D.M. \& Stanley, S.M. 1978. Principles of Paleontology. W.H. Freeman and Company, San Francisco.

Raup, D.M., McGhee, G.R., Jr. \& McKinney, F.K. 2006. Source code for theoretical morphologic simulation of helical colony form in the Bryozoa. Palaeontologia Electronica, 9(2), 7A.

Raup, D.M., Gould, S.J., Schopf, T.J.M. \& Simberloff, D.S. 1973. Stochastic models of phylogeny and the evolution of diversity. The Journal of Geology, 81, 525-542.

Richards, R.J. 1992. The Meaning of Evolution: The Morphological Construction and Ideological 
Reconstruction of Darwin's Theory. The University of Chicago Press, Chicago.

Rudwick, M.J.S. 1961. The feeding mechanism of the Permian brachiopod Prorichthofenia. Palaeontology, 3, 450-471.

Rudwick, M.J.S. 1964. The inference of function from structure in fossils. The British Journal for the Philosophy of Science, 15, 27-40.

Rudwick, M.J.S. 1972. The Meaning of Fossils: Episodes in the History of Palaeontology. Macdonald \& Co., London, \& American Elsevier, New York.

Schopf, T.J.M. (ed.) 1972. Models in Paleobiology. Freeman, Cooper \& Company, San Francisco, California.

Seilacher, A. 1970. Arbeitskonzept zur KonstruktionsMorphologie. Lethaia, 3, 393-396.

Sepkoski, D. \& Raup, D.M. 2009. An interview with David M. Raup. In: The Paleobiological Revolution: Essays on the Growth of Modern Paleontology (eds Sepkoski, D.
\& Ruse, M.). The University of Chicago Press, Chicago, 459-471.

Sepkoski, J.J., Jr. 1989. Periodicity in extinction and the problem of catastrophism in the history of life. Journal of the Geological Society of London, 146, 7-19.

Simpson, G.G. 1944. Tempo and Mode in Evolution. Reprint 1984. Columbia University Press, New York.

Simpson, G.G. 1949. The Meaning of Evolution. A Study of the History of Life and of its Significance for Man. Yale University Press, New Haven.

Thompson, D'A.W. 1942. On Growth and Form. Reprint 1972. Cambridge University Press, Cambridge, Great Britain.

Valentine, J.W. 1969. Patterns of taxonomic and ecological structure of the shelf benthos during Phanerozoic time. Palaeontology, 12, 684-709.

Van Valen, L. 1973. A new evolutionary law. Evolutionary Theory, 1, 1-30. 